\title{
THE COMPARISON OF BILINGUAL AND MONOLINGUAL LEARNERS ABILITY IN IDENTIFYING SENTENCES USING REDUCED CLAUSE
}

\author{
Clara Herlina \\ English Department, Faculty of Language and Culture, Bina Nusantara University, \\ Jl Kemanggisan Ilir III No. 45, Kemanggisan/Palmerah, Jakarta Barat 11480 \\ claraherlina@yahoo.com
}

\begin{abstract}
English and Indonesian have similar rules in the placement of head noun in adjective clause, that is head noun precedes the clause. However, in English it is possible to reduce the clause while in Indonesian it is not possible to do it. This difference causes difficulty for students learning English especially those whose language background is different. Binus University students come from different provinces around Indonesia and thus they have different language backgrounds. The research declares the difference of this background in identifying reduced clause. They are categorized into monolinguals if they only speak Indonesian at home and bilinguals if they speak both Indonesian and their ethnic languages. The purpose of this study is to find out whether bilinguals perform better than monolinguals, or vice versa, in processing reduced clause sentences.
\end{abstract}

Keywords: reduced clause, monolingual, bilingual

\begin{abstract}
ABSTRAK
Bahasa Inggris dan Bahasa Indonesia mempunyai aturan yang mirip untuk peletak kata kerja utama di dalam adjective clause, yaitu head noun bisa mendahului klausa. Tetapi, di dalam bahasa Inggris dimungkinkan juga untuk mengurangi klausa, sementara di dalam bahasa Indonesia tidak mungkin dilakukan demikian. Perbedaan ini menyebabkan kesulitan mahasiswa yang belajar bahasa Inggris, terutama bagi mereka berlatar belakang bahasa yang berbeda. Penelitian ini menunjukkan hubungan perbedaan latar belakang bahasa tersebut untuk mengidentifikasi kalimat dengan pengurangan klausa. Kelompok yang termasuk monolingual adalah mereka yang hanya berbicara bahasa Indonesia di rumah, dan kelompok bilingual adalah mereka yang berbicara baik bahasa Indonesia dan bahasa ibu. Tujuan penelitian adalah menemukan apakah kelompok bilingual berkemampuan lebih dari pada kelompok monolingual, atau sebaliknya, dalam mengenali kalimat dengan pengurangan klausa.
\end{abstract}

Kata kunci: pengurangan klausa, monolingual, bilingual 


\section{INTRODUCTION}

In English, the head noun for an adjective clause appears before the clause itself, as in this sentence: The boy who is eating rice is crying. In Indonesian, and in some other ethnic languages in Indonesia, the head noun also appears before the adjective clause. Example: Anak yang sedang makan nasi itu sedang menangis. While in Mandarin Chinese, the head noun appears after the adjective clause. Example: Zhe ge chi fan de xiao haizi zai ku. It is possible in English for a clause to appear in a complete form or in a reduced form. Examples: (1) The boy who is eating rice is crying, (2) The boy eating rice is crying. Sentence (1) shows an adjective clause in its complete form, who is eating rice, while sentence (2) shows an adjective clause in its reduced form, eating rice. However, this is not possible in other languages above. In Indonesian, we can not have the reduced form. Example: Anak sedang makan nasi itu sedang menangis. This sentence would be considered as ungrammatical, because there are two predicates in one sentence. The relative pronoun yang is indispensable in Indonesian sentence with adjective clause.

The position of head noun and the specific construction of English adjective clause may become problematic for Indonesian students especially for those who have other language background. Indonesia consists of many provinces, each having its own language. Therefore, Binus University students coming from many places in Indonesia are possibly bilinguals or even multilingual. They must at least master Indonesian, as the national language which is taught and used in schools, and the other is their ethnic language (the language used in the place /province of origin). Interestingly, students of Chinese descendants from some provinces in Sumatra and Kalimantan use several dialects of Chinese language, such as Hakka, Hokkian, Tio Chiu or Cantonese. They do not speak the ethnic language of the provinces such as Jambi Malay, Bataknese, etc. This research will analyze the impact of students' language background in learning a foreign language such as English, particularly in identifying the reduced adjective clause. The writer will find out whether students with bilingual background perform better than students with monolingual background, or vice versa.

Definition of Bilingualism. Until present days, there has not any exact definition of bilingualism. Most of the definitions are given in terms of categories, scales and dichotomies. Bloomfield (1933:56) begins with specifying the criteria of bilingualism as 'native-like control of two languages'. This is also supported by Mackey (1962) who proposes that bilingualism is 'the ability to use more than one language'. By contrast Haugen (1953) observes that bilingualism begins when the speaker of one language can produce complete and meaningful utterance in the other language. Weinreich (1953) also says that bilingualism involves the practice of alternatively using two languages.

Webster's dictionary (1961) defines bilingual as 'having or using two languages especially as spoken with the fluency characteristic of a native speaker; a person using two languages especially habitually and with control like that of a native speaker' and bilingualism as 'the constant oral use of two languages'. This definition supports what Bloomfield has proposed about 'perfect bilinguals'. In contrast, Macnamara (1967) proposes that a bilingual is anyone who possesses a minimal competence in only one of the four language skills, listening comprehension, speaking, reading and writing, in a language other than his mother tongue. In short, all of the definitions show a spectrum from a rigorous expectation of totally balanced bilingual to a loose requirement of the mere ability in using two languages.

Degree of Bilingualism. From the discussion of the definitions of bilingualism above, it can be concluded that bilingual ability is characterized by the proficiency in using the two languages. Consequently, there are several degrees of bilingualism. Chin and Wigglesworth (2007) provide four degrees of bilinguals. The highest degree is balanced bilingual (a term proposed by Lambert et al 
(1959) who is fully competent in both languages. However, a perfect or balanced bilingual is hardly possible as Fishman (1972) said that 'bilinguals are rarely equally fluent in both languages in all topics'. Baetens-Beardsmore (1982) also supports that a balanced bilingual is nearly impossible to achieve. The next degree is a dominant bilingual who is dominant in one language, but does not apply to all domains and the other language is the subordinate one. Then, there is passive or recessive bilingual who is gradually losing one's language competence in one language because of disuse. The lowest one is semilingual or limited bilingual who lacks proficiency in both languages. According to Hansegard (1968) a semilingual has a deficit in six language competence: size of vocabulary, correctness of language unconscious processing of language, language creation, mastery of function of language, meaning and imagery, compared to a monolingual. This semilingualism is often blamed for low academic achievement of minority children.

Dimension of Bilinguality. Hamers and Blanc (2000) proposed 6 dimensions of bilinguality, which are (1) Relative competence. According to competence in both languages, there are balanced bilinguals and dominant bilinguals; (2) Cognitive organization. According to cognitive organization, there are compound bilinguals and coordinate bilinguals; (3) Age of acquisition. According to age of acquisition, there are childhood, adolescent, and adult bilinguals; (4) Exogeneity. According to the presence of L2 community in environment, there are endogenous bilinguals and exogeneous bilinguals; (5) Social and cultural status. According to relative status of the two languages, there are additive and subtractive bilinguals; (6) Cultural identity. According to the group membership and cultural identity, there are bicultural bilinguals, L1 monocultural bilinguals, L2 monocultural bilinguals, and deculturated bilinguals.

Bilingualism and Cognitive Development. The proposition whether bilingualism affect cognitive content or thought process has aroused controversial debate. Earlier studies demonstrate the negative consequences of bilingual development. Studies by Pintner \& Keller (1922) reported a 'linguistic handicap' in bilingual children and Saer (1923) spoke of 'mental confusion' to describe the bilingual's cognitive functioning. Bilingualism is said to be the cause of a diminished functioning in the two languages. Jespersen (1922: 148) also expressed a negative opinion:

It is, of course, an advantage for a child to be familiar with two languages; but without doubt the advantage may be, and generally is, purchased too dear. First of all the child in question hardly learns either of the two languages as perfectly as he would have done if he had limited himself to one. It may seem on the surface, as if he talked just like a native, but he does not really command the fine points of the language. Secondly, the brain effort required to master the two languages instead of one certainly diminished the child's power of learning other things which might and ought to be learnt.

Other prominent linguists, such as Hakuta (1986) also expressed equally negative views. They claim that bilingual children are handicapped in their language growth and retarded in their native language development. However, a series of studies by Peal \& Lambert (1962) show the positive effects of bilingualism. Lambert (1977:30) summarizes the positive advantages of bilingualisms as follows:

There is, then, an impressive array of evidence accumulating that argues plainly against the common sense notion that becoming bilingual, that is, having two strings to one's bow or two linguistic systems within one's brain naturally divides a person's cognitive resources and reduces his efficiency of thought. Instead, one can now put forward a very persuasive argument that there is a definite cognitive advantage for bilingual children in the domain of cognitive flexibility.

Since Peal and Lambert (1962) study, there have been empirical studies in various countries in the western World, Asia and Africa which detailed the cognitive advantages of the bilingual child. Some of the advantages are (1) A greater ability in reconstructing perceptual situations (Balkan, 1970), (2) A greater sensitivity to semantic relations between words (Cummins, 1978), (3) A greater degree of divergent thinking (Scott, 1973; Ben-Zeev, 1972), (4) Better performance in rule-discovery tasks 
(Bain, 1975), (5) Better at correction of ungrammatical sentences (Diaz, 1985), and (6) Better at analogical reasoning tasks (Diaz \& Klinger, 1991). Chin (2007) also reports that bilingualism can have an enhancing effect on the learning of a third language. Bild \& Swain (1989) and Clyne (2004) claim that bilinguals are more effective and persistent learners of target language than monolingual learners.

Threshold Theory. Related to negative and positive effects of bilingualism, Toukoma Skutnabb-Kangas cited in Hoffman (1991:89), offers a threshold theory which correlate the effects of bilingualism with the degree of bilingualism. Table 1 summarizes the theory.

Table 1 Treshold Theory

\begin{tabular}{lll}
\hline \multicolumn{1}{c}{ Type of Bilingualism } & \multicolumn{1}{c}{ Effect } & Threshold Level \\
\hline Balanced bilinguals & $\begin{array}{l}\text { Positive cognitive effect } \\
\text { Dominant bilinguals }\end{array}$ & Higher threshold level \\
& $\begin{array}{l}\text { Neither positive nor } \\
\text { negative effect }\end{array}$ & \\
Semilinguals & Negative cognitive effect & Lower threshold level \\
\hline
\end{tabular}

Measuring Language Competence. To measure the learners' competence in using a language, we can give them test. Henning (1987) proposes a range of types of test, of which the most common are (1) Proficiency test: to measure a person language ability irrespective of the type of language exposure the person may have had, for example IELT and TOEFL test; (2) Achievement test: to evaluate the language learned in a specific language instruction program related to curriculum; (3) Diagnostic test: to identify areas of language strengths and weaknesses for providing additional assistance later; and (4) Placement test: to identify the most appropriate place for learners in classes according to his proficiency level.

Reduced Adjective Clause and Reduced Adverb Clause. An adjective clause modifies a preceding noun or a pronoun. The noun or pronoun being modified is called the antecedent. The normal position of an adjective clause is immediately after the noun or pronoun to which it refers. The man who had stolen the money was sought by the police. The antecedent of the adjective clause who had stolen the money is the man. Adjective clauses can appear in a reduced form. In the reduced form, the adjective clause connector and the be-verb that directly follow it are omitted. Examples: (1) The woman who is waving to us is the tour guide, (2) The woman waving to us is the tour guide, (3) The letter which was written last week arrived today, (4) The letter written last week arrived today, (5) The pitcher that is on the table is full of ice tea, and (6) The pitcher on the table is full of ice tea.

In the reduced form the connector who, which or that is omitted along with the be-verb, is or was. If there is no be-verb in the adjective clause, the connector is omitted and the verb is changed into the -ing form. Examples: (1) I don't understand the article which appears in today's news research, and (2) I don't understand the article appearing in today's news research.

Adverb clauses can also appear in a reduced form. In the reduced form, the adverb connector remains, but the subject and be-verb are omitted. Examples: (1) Although he is rather unwell, the speaker will take part in the seminar, and (2) Although unwell, the speaker will take pat in the seminar.

If there is no be-verb in the adverb clause, the subject is omitted and the main verb is changed into the -ing form. Examples: (1) Although he feels rather sick, the speaker will take part in the seminar, (2) Although feeling rather sick, the speaker will take part in the seminar. 


\section{RESEARCH METHODS}

\section{Participants}

The participants for this study are 64 Binus students who are taking English III subject. They are then divided into two groups: Monolinguals and Bilinguals. Monolinguals are those who can only speak Indonesian in all domains, while bilinguals are those who can use two languages. The criteria for bilinguality are: (1) They master other ethnic languages beside Indonesian, (2) They have learnt the language since childhood, (3) They use the language actively at least in family domain, and (4) They come from places outside Jakarta.

The bilinguals are further categorized according to the language of origin. Those who speak dialects of Chinese (Hakka, Hokkian, Tio Chiu, Cantonese, etc.) are grouped into one sub-category and the other sub- category are those who speak Indonesian ethnic languages (Sundanese, Javanese, Bataknese, etc.) The above categorization gives the following number: Monolinguals: 31 persons and Bilinguals: 31 persons (16 Chinese languages +15 Ethnic languages).

\section{Instrument for Data Collection}

The instrument of this study is in the form of grammar test. The test is taken from Deborah Phillips's Longman Complete Course of the TOEFL Test. The particular skill is about Reduced adjective and adverb clause. The test consists of 20 sentences, in which the students are required to identify the ungrammatical sentences and give correction of the incorrect sentences. For example: The children sat in the fancy restaurant found it difficult to behave. Students have to determine whether this sentence is correct or incorrect, then give the correction such as: The children sitting in the fancy restaurant found it difficult to behave.

\section{Data Analysis}

The test results will be analyzed statistically using SPSS 17.0 program to find out the following: (1) The ability of monolingual and bilingual learners in identifying ungrammatical sentences, (2) The ability of monolingual and bilingual learners in correcting ungrammatical sentences, and (3) The correlation between bilingualism and learners' competence in identifying and correcting ungrammatical sentences.

\section{RESULTS AND DISCUSSION}

\section{Identification of Reduced Clause}

Table 2 shows that the students' ability to identify the ungrammatical sentences using reduced clause is more or less the same. Monolingual students can get the score of 7.8 while the bilingual students get 7.4. Monolingual students get a slightly better score than bilingual students. This means the average number of sentences that the monolingual students can identify correctly is 15.6 sentences out of 20 sentences. On the other hand, bilingual students can only identify 14.8 out of 20 sentences. The difference is so small that it is not considered significant as it is proven in the following table showing independent samples test: 
Table 2 Comparison of Mean of Identification

Group Statistics

\begin{tabular}{lllccc}
\hline \multicolumn{1}{c}{ mono } & N & Mean & Std. Deviation & Std. Error Mean \\
\hline \multirow{2}{*}{ identify } & monolingual & 31 & 7.806 & 1.7160 & .3082 \\
& bilingual & 31 & 7.387 & 1.5422 & .2770 \\
\hline
\end{tabular}

Table 3 Independent Samples Test

\begin{tabular}{|c|c|c|c|c|c|c|c|c|c|}
\hline & \multicolumn{2}{|c|}{$\begin{array}{c}\text { Levene's Test for } \\
\text { Equality of } \\
\text { Variances }\end{array}$} & \multicolumn{7}{|c|}{ t-test for Equality of Means } \\
\hline & \multirow[b]{2}{*}{$\mathrm{F}$} & \multirow[b]{2}{*}{ Sig. } & \multirow[b]{2}{*}{$\mathrm{t}$} & \multirow[b]{2}{*}{ df } & \multirow[b]{2}{*}{$\begin{array}{l}\text { Sig. (2- } \\
\text { tailed) }\end{array}$} & \multirow[b]{2}{*}{\begin{tabular}{|c|} 
Mean \\
Difference
\end{tabular}} & \multirow[b]{2}{*}{\begin{tabular}{|l|} 
Std. Error \\
Difference
\end{tabular}} & \multicolumn{2}{|c|}{$\begin{array}{l}\text { 95\% Confidence } \\
\text { Interval of the } \\
\text { Difference }\end{array}$} \\
\hline & & & & & & & & Lower & Upper \\
\hline $\begin{array}{c}\text { identify Equal variances } \\
\text { assumed }\end{array}$ & .036 & .851 & 1.012 & 60 & .316 & .4194 & .4144 & -.4095 & 1.2482 \\
\hline $\begin{array}{l}\text { Equal variances } \\
\text { not assumed }\end{array}$ & & & 1.012 & 59.329 & .316 & .4194 & .4144 & -.4097 & 1.2484 \\
\hline
\end{tabular}

From the SPSS result it can be seen that the significance 0.316 is more than $\alpha=0.05$ for equal variance assumed. This means that bilingual students are not better than monolingual students in identifying ungrammatical sentences. In other words, bilinguals as well as monolinguals have similar ability in recognizing whether a sentence is grammatical or not.

\section{Correction of Ungrammatical Reduced Clause Sentences}

When asked to make correction, most students can not do it properly. So, in general, they only get 3-4 score out of 10 . That means they can only correct 3-4 sentences. Some even do not make corrections at all, so they get 0 scores for correction. Interestingly, from 31 monolingual students, 7 students got 0 score; while from bilingual students only 2 got 0 score.

The ability to identify whether a sentence is grammatical or not seems unrelated to the ability to make correction. Therefore, even if a student can identify that the sentence The suspect can be seen in the photographs were just released by the police is incorrect, he can not make a correct revision of that sentence. He wrote The suspected can be seen in the photographs were just released by the police. The correct one should be The suspect seen in the photographs were just released by the police.

However, the overall result shows that the mean score of monolingual students is slightly higher than that of bilingual students as shown in Table 4. 
Table 4 Comparison of Mean of Correction

\begin{tabular}{lllccc}
\multicolumn{5}{c}{ Group Statistics } \\
\hline \multirow{2}{*}{ correction } & mono & $\mathrm{N}$ & Mean & Std. Deviation & Std. Error Mean \\
& monolingual & 31 & 4.161 & 3.1102 & .5586 \\
& bilingual & 31 & 3.677 & 2.5480 & .4576 \\
\hline
\end{tabular}

\begin{tabular}{|c|c|c|c|c|c|c|c|c|c|c|}
\hline \multicolumn{11}{|c|}{ Independent Samples Test } \\
\hline & & \multicolumn{2}{|c|}{$\begin{array}{c}\text { Levene's Test for } \\
\text { Equality of } \\
\text { Variances }\end{array}$} & \multicolumn{7}{|c|}{ t-test for Equality of Means } \\
\hline & & \multirow[b]{2}{*}{$\mathrm{F}$} & \multirow[b]{2}{*}{ Sig. } & \multirow[b]{2}{*}{$\mathrm{t}$} & \multirow[b]{2}{*}{ df } & \multirow[b]{2}{*}{$\begin{array}{c}\text { Sig. } \\
(2- \\
\text { tailed })\end{array}$} & \multirow[b]{2}{*}{$\begin{array}{c}\text { Mean } \\
\text { Difference }\end{array}$} & \multirow[b]{2}{*}{$\begin{array}{l}\text { Std. Error } \\
\text { Difference }\end{array}$} & \multicolumn{2}{|c|}{$\begin{array}{l}95 \% \text { Confidence } \\
\text { Interval of the } \\
\text { Difference }\end{array}$} \\
\hline & & & & & & & & & Lower & Upper \\
\hline \multirow[t]{2}{*}{ correction } & $\begin{array}{l}\text { Equal } \\
\text { variances } \\
\text { assumed }\end{array}$ & 3.837 & .055 & .670 & 60 & .505 & .4839 & .7221 & -.9606 & 1.9283 \\
\hline & $\begin{array}{l}\text { Equal } \\
\text { variances } \\
\text { not } \\
\text { assumed }\end{array}$ & & & .670 & 57.764 & .505 & .4839 & .7221 & -.9618 & 1.9295 \\
\hline
\end{tabular}

The above SPSS calculation showing the significance value 0.505 for the equality of variances also indicates that bilingualism does not account for score of correction. That means bilingual students have the same ability in correcting ungrammatical sentences with the monolingual students. The similar result occurs when students result is compared based on their language of origin as shown in table 5 .

Table 5 Comparison of Means of Chinese and Ethnic Languages' Students

\begin{tabular}{lllcrrr}
\multicolumn{7}{c}{ Group Statistics } \\
\hline \multirow{2}{*}{ correction } & Bahasa & N & & Mean & Std. Deviation & Std. Error Mean \\
& daerah & 15 & 3.667 & 2.8200 & .7281 \\
identify & chinese & 16 & 3.688 & 2.3585 & .5896 \\
& daerah & 15 & 7.367 & 1.6847 & .4350 \\
& chinese & 16 & 7.406 & 1.4517 & .3629 \\
\hline
\end{tabular}

There is no significant difference in scores between monolingual students whose languages are Chinese or ethnic languages.

\section{Correlation between Bilingualism and Proficiency}

Pearson Product Moment Correlation coefficient is used to measure the relation between two variables: bilingualism and students' proficiency in identifying ungrammatical sentences. The result is shown in table 6 . 
Table 6 Correlation between Bilingualism and Identify

\begin{tabular}{llrr}
\multicolumn{3}{c}{ Correlations } & \\
\hline \multirow{4}{*}{ mono } & mono & \multicolumn{1}{c}{ identify } \\
& Pearson Correlation & 1 & -.130 \\
& Sig. (2-tailed) & & .316 \\
& N & 62 & 62 \\
identify & Pearson Correlation & -.130 & 1 \\
& Sig. (2-tailed) & .316 & \\
& N & 62 & 62 \\
\hline
\end{tabular}

The table shows a low negative correlation coefficient of -0.130 and the significance 0.316 is bigger than $\alpha=0.05$. This means that there is no significant correlation between students' bilingualism and their scores in identifying ungrammatical sentences.

\section{CONCLUSION}

It is still debatable whether bilingualism can give positive or negative effects to learners, especially to those who are learning a foreign language (third language). In the study of 64 Binus University students learning English, the writer found the following results. First, bilingual students have more or less the same score as monolingual students in identifying mistakes in reduced clause sentences. In fact, monolingual students (7.8) are slightly better than bilingual students (7.4). Second, monolingual students (4.2) are better than bilingual students (3.7) in correcting the mistakes in reduced clause sentences. Third, bilingual students whose mother tongues are Chinese languages and Indonesian ethnic languages have similar performance in identifying and correcting ungrammatical reduced clause sentences. Fourth, there is a low negative correlation between bilingualism of the students and their ability in identifying and correcting ungrammatical reduced clause sentences. From the above results, the writer concludes that bilingual students are not performing better than monolingual students in learning a foreign language (especially English). In the case of Binus students, most of the bilingual students came from several provinces outside Jakarta, such as Jambi, Riau, West Kalimantan, Central Java; while monolinguals came from Jakarta and other big cities in Java where access to a foreign language (English) is readily available. So, the place of origin may also become a determining factor in the mastery of a foreign language.

\section{REFERENCES}

Baetens-Beardsmore, H. (1982) Bilingualism: Basic principles, Clevedon, Avon: Multilingual Matters.

Bain, B.C. (1975) Toward an integration of Piaget and Vygotsky: Bilingual considerations. Linguistics, 160, 5-20.

Balkan. L. (1970). Les effets du bilinguisme francais-anglais sur les aptitudes intellectuelles, Brussells: Aimav.

Ben-Zeev, S. (1972). The influence of bilingualism on cognitive development and cognitive strategy. Unpublished Ph.D. dissertation, University of Chicago. 
Bild, E.R., and Swain, M. (1989). Minority language students in a French immersion program: Their French proficiency. Journal of Multilingual and Multicultural Development, 10, 255-274.

Bloomfield, L. (1933) Language, New York: Holt.

Chin, N.B., and Wigglesworth, G. (2007). Bilingualism: An advance resource book, London: Routledge.

Clyne, M. (2004). Toward an agenda for developing multilingual communication with a community base. In: House, Juliane \& Rehbein, Jochen (Eds.) Multilingual Communication. Hamburg Studies on Multilingualism 3. Amsterdam and Philadelphia: John Benjamins, 1-17

Cummins, J. (1978). Metalinguistic development of children in bilingual education programs: Data from Irish and Canadian Ukranian-English programs. In Paradis, M. (Ed.), The Fourth Locus Forum 1977. Columbia. S.C.: Hornbeam Press.

Diaz. R.M. (1985). Thought and two languages: The impact of bilingualism on cognitive development. Review of Research in Education, 10, 23-54.

Diaz, R.M., and Kingler, C. (1991). Towards an explanatory model of the interaction between bilingualism and cognitive development. In E. Bialystok (Ed.). Language processing in bilingual children (pp. 167-192). Cambridge: Cambridge University Press.

Fishman, J.A. (1972). Language and nationalism, Rowley, Mass: Newbury House Publishers.

Hakuta, K. (1986). Mirror of language: The debate on bilingualism, New York: Basic Books.

Hamers, J.F., and Blanc, M. ( 2000). Bilinguality and bilingualism, Cambridge: Cambridge University Press.

Hansegård, N.E. (1968). Tvåspråkighet eller halvspråkighet? [Bilingualism or semilingualism?] Stockholm: Aldus series 253.

Haugen, E. (1953). The Norwegian language in American: A study in bilingual behavior. 2 vols. Philadelphia: University of Pennsylvania Press.

Hoffman, C. (1991). An introduction to bilingualism, London: Longman.

Hyltenstam, K., and Obler, L. (1989). Bilingualism across the life span, Cambridge: Cambridge University Press.

Jespersen, O. (1922). Language: Its nature, development, and origin, London: Allen \& Unwin.

Lambert, W., Havelka, J., and Gardner, R. (1959). Linguistic manifestations of bilingualism. American Journal of Psychology, 72, 77-82.

Lambert, W.E. (1977). The effects of bilingualism on the individual: Cognitive and socio-cultural consequences. In P. Hornby (Ed.), Bilingualism: Psychological, social, and educational implications (pp. 15-27). New York: Academic Press.

Mackey, W. (1962). The description of bilingualism. In L. Wei (ED). Bilingualism Reader. United Kingdom: Routledge. 
MacNamara, J. (1967). Bilingualism in the modern world.

Nicol, J.L. (ed.). (2000). One mind, two languages, Oxford: Blackwell Publisher.

Peal, E., and Lambert, W.E. (1962). The relation of bilingualism to Intelligence psychological monographs, 76(27), 1-23.

Phillips, D. (2000). Longman complete course for the TOEFL Test, London: Longman.

Pintner, R., and Keller, R. (1922). Intelligence test of foreign children. Journal of Educational Psychology, 20, 661-668.

Romaine, S. (2000). Bilingualism, $2^{\text {nd }}$ ed., Oxford: Blackwell Publisher.

Saer. D. J. (1923). The effects of bilingualism on intelligence. British Journal of Psychology, 14, 2538.

Scott, S. (1973). The relation of divergent thinking to bilingualism: Cause or effect?. Unpublished manuscript, McGill University.

Webster's New Collegiate Dictionary. (1961). Springfield, MA: G. \& C. Merriam.

Weinreich, U. (1953). Languages in contact, New York: The Linguistic Circle of New York.

\section{PRE TEST}

Indicate If the Sentences are Correct or Incorrect and Make Correction for the Incorrect Ones.

1. The food placing on the picnic table attracted a large number of flies.

2. The suspect can be seen in the photographs were just released by the police

3. The ointment can be applied when needed

4. When purchased at this store, the buyer gets a guarantee on all items.

5. Once purchased, the swimsuits cannot be returned.

6. Though located near the coast, the town does not get much of an ocean breeze.

7. Dissatisfied with the service at the restaurant, the meal really was not enjoyable.

8. The brand new Cadillac, purchasing less than two weeks ago, was destroyed in the accident.

9. The children sat in the fancy restaurant found it difficult to behave.

10. The medicine is not effective unless taken as directed.

11. If not completely satisfied, you can return the product to the manufacturer.

12. Though was surprised at the results, she was pleased with what she had done.

13. The application will at least be reviewed if submitted by the $15^{\text {th }}$ of the month.

14. Before decided to have surgery, you should get a second opinion.

15. When applying for the job, you should bring your letter of reference.

16. The company president, needed a vacation, boarded a plane for Bahamas.

17. Feeling weak after a long illness, Sally wanted to try to get back to work.

18. Wearing only a light sweater, she stepped out into the pouring rain.

19. When built nest during the spring nesting season, Canadian geese are fiercely territorial.

20. Kokanee salmon begin to deteriorate and die soon after spawning at the age of four. 